\title{
RENAL PARTICIPATION IN ENHANCED PRESSOR RESPONSES TO NORADRENALINE IN PATIENTS GIVEN HEXAMETHONIUM
}

\author{
By A. C. CORCORAN, WILLIAM E. WAGNER, 1 AND IRVINE H. PAGE \\ (From the Research Division, The Cleveland Clinic Foundation and The Frank E. Bunts \\ Educational Institute, Cleveland, Ohio)
}

(Submitted for publication January 9, 1956; accepted April 16, 1956)

Ganglion-blockers, such as tetra-ethylammonium (TEA) and hexamethonium, enhance responsiveness to vasoactive agents, both pressor and depressor (1). In dogs, the renal arterial bed seems to contribute to the change in blood pressure response since, after giving TEA, adrenaline causes a larger increase and isopropylnoradrenaline (Isupre1 ${ }^{\circledR}$ ) a larger decrease in renal vascular resistance than in the untreated state (2). The present study was undertaken with the aim of determining responsiveness to noradrenaline in hypertensive patients given hexamethonium and the participation in this of the renal circulation.

\section{PROCEDURES}

Brachial auscultatory arterial pressures and plasma clearances of p-aminohippurate (PAH) and mannitol (procedure described in Reference 3 ) were measured in successive 10-minute periods, under control and test conditions, in the supine position. All the patients had severe hypertensive disease but none of them had signs of congestive heart failure at the time of study. Signs of failure, present on admission in 3 of the patients, had been cleared by diet, digitalis and diuretics for at least a week before test.

Four series of studies were done. In the first (I), 6 patients, were observed as below during a 30-minute control period interval; they were then given noradrenaline by infusion at rates of 4 or 5 micrograms per minute over about 40 minutes, during the last 30 of which 3 urine collections were made, the urine formed during the first 10 minutes having been discarded; single intravenous injections of hexamethonium were then given in doses sufficient to decrease diastolic pressure about 10 to $20 \mathrm{~mm} . \mathrm{Hg}$ and the effects of this observed over another 40 minutes in the same way as had been those of noradrenaline; at the end of this time noradrenaline was again infused in the same dose as before and the observations repeated. Blood pressures (measured at intervals of 2 to 5 minutes), plasma clearances and rates of urine flow were averaged for each of the four sets of three $10-\mathrm{min}$ ute urine collection periods.

\footnotetext{
1 Present Address: Research Department, Department of Clinical Investigation, Ciba Pharmaceutical Products Inc., Summit, N. J.
}

In the second series (II), 4 patients were given noradrenaline after control observations as above. In the third series (III), 6 patients were given hexamethonium after control study and, in the fourth (IV), 7 patients under chronic treatment with hexamethonium were given noradrenaline as above.

The plasma clearance of PAH at low plasma concentrations $\left(\mathrm{C}_{\mathrm{PAB}}\right)$ was taken as equivalent to renal plasma flow (RPF) and the plasma clearance of mannitol times 1.1 (to allow for 10 per cent reabsorption) was taken as equal to glomerular filtration rate (GFR). Urine minute volume (V) was estimated from the excess over that of the $100 \mathrm{ml}$. of $\mathrm{NaCl}$ used to rinse the bladder. Renal vascular resistance ( $R$ ) was calculated as $\mathrm{Pm}-5$ / $\mathrm{RPF}$, taking as $\mathrm{Pm}$ (mean arterial pressure) the mean of the averages of systolic and diastolic pressure over the respective minute interval of study.

\section{RESULTS}

The observations are compiled in Tables I and II. Table III condenses the data by listing the average magnitudes of these effects as ratios of test to control levels.

\section{Noradrenaline alone}

Series $I$ and $I I$. This caused a light increase in arterial pressure in 9 of the 10 patients. It increased renal vascular resistance in all, this proportionately more than it did arterial pressure. It elicited increases in urine flow in 7 of the 10 tests.

\section{Hexamethonium alone-single injection}

Series $I$ and III. This agent, in the widely varying doses used to elicit the desired moderate depressor effects, had irregular effects on renal resistance, which was increased in 3 and decreased in 8 of the 12 tests with no change in 1 . Renal plasma flow was decreased to some extent in 10 of the 12 tests; glomerular filtration rate and urine flow were decreased in all.

The association between changes in filtration 
TABLE I

Effects of noradrenaline, hexamethonium and of noradrenaline in the presence of hexamethonium*

\begin{tabular}{|c|c|c|c|c|c|c|c|c|}
\hline No. & Diag. & RPF & GFR & $\mathbf{F F}$ & $\underset{m m .}{\text { B.P. }} \dot{g}$ & $\mathbf{R}$ & $\mathbf{v}$ & Treatment \\
\hline 1 & EHM & $\begin{array}{l}198 \\
188 \\
194 \\
213\end{array}$ & $\begin{array}{l}40 \\
39 \\
32 \\
34\end{array}$ & $\begin{array}{l}.20 \\
.21 \\
.17 \\
.16\end{array}$ & $\begin{array}{l}225 / 121 \\
225 / 126 \\
199 / 115 \\
214 / 128\end{array}$ & $\begin{array}{l}.84 \\
.93 \\
.78 \\
.78\end{array}$ & $\begin{array}{l}1.2 \\
2.3 \\
0.4 \\
0.8\end{array}$ & $\begin{array}{l}\text { None } \\
\text { N-A } 4 \mu \text { per min. } \\
\text { Hexam. } 75 \mathrm{mg} . \\
\text { N-A } 4 \mu \text { per min. }\end{array}$ \\
\hline 3 & EHM & $\begin{array}{l}414 \\
365 \\
398 \\
386\end{array}$ & $\begin{array}{l}108 \\
112 \\
102 \\
101\end{array}$ & $\begin{array}{l}.26 \\
.21 \\
.26 \\
.26\end{array}$ & $\begin{array}{l}211 / 118 \\
237 / 122 \\
183 / 104 \\
218 / 120\end{array}$ & $\begin{array}{l}.39 \\
.48 \\
.32 \\
.42\end{array}$ & $\begin{array}{l}4.8 \\
7.2 \\
2.0 \\
4.5\end{array}$ & $\begin{array}{l}\text { None } \\
\text { N-A } 4 \mu \text { per min. } \\
\text { Hexam. } 50 \mathrm{mg} \text {. } \\
\text { N-A } 4 \mu \text { per min. }\end{array}$ \\
\hline 4 & EHM & $\begin{array}{l}465 \\
336 \\
344 \\
359\end{array}$ & $\begin{array}{r}117 \\
99 \\
88 \\
105\end{array}$ & $\begin{array}{l}.25 \\
.29 \\
.28 \\
.29\end{array}$ & $\begin{array}{l}213 / 136 \\
236 / 148 \\
190 / 129 \\
225 / 148\end{array}$ & $\begin{array}{l}.37 \\
.56 \\
.45 \\
.51\end{array}$ & $\begin{array}{l}8.3 \\
6.3 \\
1.7 \\
4.5\end{array}$ & $\begin{array}{l}\text { None } \\
\text { N-A } 4 \mu \text { per min. } \\
\text { Hexam. } 5 \text { mg. } \\
\text { N-A } 4 \mu \text { per min. }\end{array}$ \\
\hline 5 & $\mathbf{E H}$ & $\begin{array}{l}415 \\
353 \\
318 \\
334\end{array}$ & $\begin{array}{r}112 \\
99 \\
72 \\
83\end{array}$ & $\begin{array}{l}.27 \\
.28 \\
.23 \\
.25\end{array}$ & $\begin{array}{l}194 / 106 \\
205 / 112 \\
166 / 96 \\
180 / 106\end{array}$ & $\begin{array}{l}.36 \\
.43 \\
.41 \\
.41\end{array}$ & $\begin{array}{l}4.0 \\
4.6 \\
0.75 \\
0.8\end{array}$ & $\begin{array}{l}\text { None } \\
\text { N-A } 4 \mu \text { per min. } \\
\text { Hexam. } 10 \mathrm{mg} . \\
\text { N-A } 4 \mu \text { per min. }\end{array}$ \\
\hline 7 & EHM & $\begin{array}{l}169 \\
142 \\
140 \\
133\end{array}$ & $\begin{array}{l}38 \\
30 \\
26 \\
29\end{array}$ & $\begin{array}{l}.22 \\
.21 \\
.19 \\
.22\end{array}$ & $\begin{array}{l}185 / 120 \\
204 / 125 \\
120 / 85 \\
146 / 100\end{array}$ & $\begin{array}{r}.89 \\
1.13 \\
.69 \\
.89\end{array}$ & $\begin{array}{l}2.3 \\
2.7 \\
0.25 \\
0.3\end{array}$ & $\begin{array}{l}\text { None } \\
\text { N-A } 5 \mu \text { per min. } \\
\text { Hexam. } 15 \mathrm{mg} . \\
\text { N-A } 5 \mu \text { per min. }\end{array}$ \\
\hline 9 & EHS & $\begin{array}{l}251 \\
201 \\
170 \\
235\end{array}$ & $\begin{array}{l}68 \\
55 \\
47 \\
50\end{array}$ & $\begin{array}{l}.27 \\
.27 \\
.28 \\
.21\end{array}$ & $\begin{array}{l}185 / 106 \\
195 / 110 \\
134 / 93 \\
182 / 120\end{array}$ & $\begin{array}{l}.56 \\
.74 \\
.64 \\
.64\end{array}$ & $\begin{array}{l}8.5 \\
6.0 \\
0.1 \dagger \\
2.4\end{array}$ & $\begin{array}{l}\text { None } \\
\text { N-A } 5 \mu \text { per min. } \\
\text { Hexam. } 16 \mathrm{mg} . \\
\text { N-A } 5 \mu \text { per min. }\end{array}$ \\
\hline
\end{tabular}

* Renal effects of noradrenaline infusion (N-A) and hexamethonium administration (Hexam.) and of noradrenaline infusion after hexamethonium as measured from renal plasma flow (RPF = plasma clearance of PAH), and glomerular filtration rate both in $\mathrm{ml}$. per min. per $1.73 \mathrm{sq} . \mathrm{m}$. of body surface (GFR = plasma mannitol clearance times 1.1 ), filtration fraction (FF $=\mathrm{GFR} / \mathrm{RPF})$ and averages of arterial pressure ( $\mathrm{Pm}=$ systolic + diastolic/2), renal vascular resistance $\left(R=\mathrm{Pm}-5 / \mathrm{C}_{\mathrm{PAB}}\right)$, and urine volume, ml. per min. $(\mathrm{V})$ in 6 patients with severe $(\mathrm{S})$ or malignant $(\mathrm{M})$ essential hypertension $(\mathrm{EH})$.

† Estimated maximum of urine flow during oliguria.

rate and urine flow in these experiments is shown in Figure 1A. This shows that, during the 40 to 50-minute interval after a single injection of hexamethonium, the antidiuresis which occurred was consistently associated with decreased glomerular filtration. With one exception, the changes in urine flow occurred in rough proportion to changes in filtration rate and small decreases in filtration elicited large decreases in urine flow. The effects resemble those described in previous reports (4-7).

\section{Pressor effect of noradrenaline during the action of hexamethonium (a)}

Series I. Single injections of hexamethonium decreased average blood pressure by about 20 per cent. Subsequent infusion of noradrenaline at rates of 4 and 5 micrograms per minute caused consistent rises of blood pressure which averaged about 20 per cent above the post-hexamethonium level. Thus, the absolute levels of pressure at- tained during these infusions of noradrenaline were about the same as existed during the prehexamethonium noradrenaline infusions, but the $\mathrm{mm}$. $\mathrm{Hg}$ rise of pressure was much greater.

Series $I V$. Patients under chronic treatment with hexamethonium also showed increased pressor responsiveness. The mean increase of pressure average in this series was about 30 per cent. Since preinfusion pressure levels of many of these patients were already high, the levels reached during noradrenaline infusion were sometimes very high and greatly exceeded those reached in patients who had been given only single doses of hexamethonium.

\section{Renal effects of noradrenaline during the action of hexamethonium}

Series $I$ and $I V$. Noradrenaline had like renal effects in both hexamethonium-treated series. The average of the changes in renal vascular re- 
sistance indicates an increase; the response of this function, unlike that of blood pressure, was not augmented by hexamethonium. Rather, the responses were unexpectedly variable, with no sig- nificant changes in renal resistance in 3 of the 6 patients given single injections of hexamethonium and in $\mathbf{2}$ of the 7 under chronic treatment. These variable responses of renal resistance to nor-

TABLE II

Effects of noradrenaline and hexamethonium in hypertensive patients and noradrenaline in patients under chronic treatment with hexamethonium *

\begin{tabular}{|c|c|c|c|c|c|c|c|c|}
\hline No. & Diag. & RPF & GFR & FF & B.P. & $\mathbf{R}$ & $\mathbf{v}$ & Dose \\
\hline \multicolumn{9}{|c|}{ A. Noradrenaline } \\
\hline $10 A$ & EHM & $\begin{array}{l}317 \\
275\end{array}$ & $\begin{array}{l}80 \\
79\end{array}$ & $\begin{array}{l}.25 \\
.29\end{array}$ & $\begin{array}{l}224 / 134 \\
248 / 135\end{array}$ & $\begin{array}{l}.55 \\
.69\end{array}$ & $\begin{array}{l}7.8 \\
6.7\end{array}$ & $\mathrm{~N}-\mathrm{A} 5 \boldsymbol{\mu}$ per $\min$. \\
\hline 17 & EHM & $\begin{array}{l}298 \\
264\end{array}$ & $\begin{array}{l}84 \\
78\end{array}$ & $\begin{array}{l}.28 \\
.30\end{array}$ & $\begin{array}{l}189 / 115 \\
192 / 110\end{array}$ & $\begin{array}{l}.48 \\
.54\end{array}$ & $\begin{array}{l}2.6 \\
3.9\end{array}$ & $\mathrm{~N}-\mathrm{A} \mathbf{5} \boldsymbol{\mu}$ per min. \\
\hline 19 & EHS & $\begin{array}{l}362 \\
287\end{array}$ & $\begin{array}{l}92 \\
79\end{array}$ & $\begin{array}{l}.23 \\
.27\end{array}$ & $\begin{array}{l}200 / 115 \\
212 / 124\end{array}$ & $\begin{array}{l}.42 \\
.58\end{array}$ & $\begin{array}{l}6.1 \\
8.4\end{array}$ & $\mathrm{~N}-\mathrm{A} 4 \mu$ per min. \\
\hline 20 & EHS & $\begin{array}{l}290 \\
289\end{array}$ & $\begin{array}{l}63 \\
65\end{array}$ & $\begin{array}{l}.22 \\
.22\end{array}$ & $\begin{array}{l}190 / 122 \\
216 / 140\end{array}$ & $\begin{array}{l}.53 \\
.60\end{array}$ & $\begin{array}{l}0.9 \\
2.6\end{array}$ & $\mathrm{~N}-\mathrm{A} 5 \mu$ per min. \\
\hline \multicolumn{9}{|c|}{ B. Hexamethonium } \\
\hline $22 A$ & EHM & $\begin{array}{l}81 \\
71\end{array}$ & $\begin{array}{l}30 \\
21\end{array}$ & $\begin{array}{l}.27 \\
.30\end{array}$ & $\begin{array}{l}224 / 134 \\
158 / 196\end{array}$ & $\begin{array}{l}2.19 \\
1.75\end{array}$ & $\begin{array}{l}3.6 \\
1.2\end{array}$ & Hexam. 26 mg. \\
\hline 22B & EHM & $\begin{array}{r}96 \\
104\end{array}$ & $\begin{array}{l}31 \\
23\end{array}$ & $\begin{array}{l}.32 \\
.22\end{array}$ & $\begin{array}{l}205 / 120 \\
188 / 144\end{array}$ & $\begin{array}{l}1.65 \\
1.40\end{array}$ & $\begin{array}{l}6.8 \\
1.5\end{array}$ & Hexam. 20 mg. \\
\hline 23 & EHM & $\begin{array}{l}176 \\
138\end{array}$ & $\begin{array}{l}62 \\
35\end{array}$ & $\begin{array}{l}.35 \\
.25\end{array}$ & $\begin{array}{l}210 / 136 \\
200 / 138\end{array}$ & $\begin{array}{l}1.00 \\
0.88\end{array}$ & $\begin{array}{l}2.6 \\
0.75\end{array}$ & Hexam. 13 mg. \\
\hline 24 & EHS & $\begin{array}{l}324 \\
330\end{array}$ & $\begin{array}{l}72 \\
65\end{array}$ & $\begin{array}{l}.22 \\
.20\end{array}$ & $\begin{array}{l}230 / 120 \\
160 / 97\end{array}$ & $\begin{array}{l}.51 \\
.38\end{array}$ & $\begin{array}{l}4.8 \\
0.5\end{array}$ & Hexam. 13 mg. \\
\hline 25 & EHS & $\begin{array}{l}312 \\
322\end{array}$ & $\begin{array}{l}82 \\
76\end{array}$ & $\begin{array}{l}.26 \\
.24\end{array}$ & $\begin{array}{l}200 / 144 \\
168 / 130\end{array}$ & $\begin{array}{l}.53 \\
.44\end{array}$ & $\begin{array}{l}1.7 \\
0.6\end{array}$ & Hexam. 36 mg. \\
\hline 26 & EHM & $\begin{array}{l}234 \\
174\end{array}$ & $\begin{array}{l}50 \\
32\end{array}$ & $\begin{array}{l}.22 \\
.18\end{array}$ & $\begin{array}{l}185 / 115 \\
137 / 90\end{array}$ & $\begin{array}{l}.62 \\
.62\end{array}$ & $\begin{array}{l}2.2 \\
0.6\end{array}$ & Hexam. 28 mg. \\
\hline \multicolumn{9}{|c|}{ C. Noradrenaline during chronic hexamethonium treatment } \\
\hline 2 & EHM & $\begin{array}{r}109 \\
91\end{array}$ & $\begin{array}{l}33 \\
30\end{array}$ & $\begin{array}{l}.30 \\
.33\end{array}$ & $\begin{array}{l}196 / 120 \\
260 / 147\end{array}$ & $\begin{array}{l}1.39 \\
2.19\end{array}$ & $\begin{array}{l}3.1 \\
4.6\end{array}$ & $\mathrm{~N}-\mathrm{A} 4 \mu$ per min. \\
\hline 8 & EHM & $\begin{array}{l}159 \\
159\end{array}$ & $\begin{array}{l}43 \\
50\end{array}$ & $\begin{array}{l}.27 \\
.31\end{array}$ & $\begin{array}{l}200 / 140 \\
278 / 170\end{array}$ & $\begin{array}{l}1.04 \\
1.37\end{array}$ & $\stackrel{5}{12.4}$ & $\mathrm{~N}-\mathrm{A} \mathrm{S}_{\boldsymbol{\mu}}$ per $\mathrm{min}$ \\
\hline $10 \mathrm{~B}$ & EHM & $\begin{array}{l}293 \\
324\end{array}$ & $\begin{array}{l}62 \\
75\end{array}$ & $\begin{array}{l}.21 \\
.23\end{array}$ & $\begin{array}{l}185 / 106 \\
250 / 135\end{array}$ & $\begin{array}{l}0.48 \\
0.58\end{array}$ & $\begin{array}{l}0.4 \\
3.3\end{array}$ & $\mathrm{~N}-\mathrm{A} 5 \boldsymbol{\mu}$ per $\mathrm{min}$ \\
\hline 13 & EHM & $\begin{array}{l}240 \\
270\end{array}$ & $\begin{array}{l}67 \\
73\end{array}$ & $\begin{array}{l}.28 \\
.27\end{array}$ & $\begin{array}{l}210 / 140 \\
232 / 146\end{array}$ & $\begin{array}{l}.70 \\
.68\end{array}$ & $\begin{array}{l}5.6 \\
5.6\end{array}$ & $\mathrm{~N}-\mathrm{A} \mathbf{5} \boldsymbol{\mu}$ per $\min$ \\
\hline $14 B$ & EHM & $\begin{array}{l}263 \\
167\end{array}$ & $\begin{array}{l}46 \\
48\end{array}$ & $\begin{array}{l}.28 \\
.29\end{array}$ & $\begin{array}{l}194 / 128 \\
216 / 137\end{array}$ & $\begin{array}{r}.96 \\
1.03\end{array}$ & $\begin{array}{l}5.5 \\
8.8\end{array}$ & $\mathrm{~N}-\mathrm{A} 4 \mu$ per min. \\
\hline 16 & EHS & $\begin{array}{l}363 \\
369\end{array}$ & $\begin{array}{r}99 \\
119\end{array}$ & $\begin{array}{l}.27 \\
.32\end{array}$ & $\begin{array}{l}174 / 118 \\
230 / 134\end{array}$ & $\begin{array}{r}0.39 \\
.49\end{array}$ & 17.7 & N-S $4.6 \mu$ per min. \\
\hline 1 & EHM & $\begin{array}{l}259 \\
244\end{array}$ & $\begin{array}{l}43 \\
55\end{array}$ & $\begin{array}{l}.17 \\
.23\end{array}$ & $\begin{array}{l}158 / 110 \\
264 / 153\end{array}$ & $\begin{array}{l}.49 \\
.83\end{array}$ & $\begin{array}{r}0.8 \\
10.7\end{array}$ & N-A $4 \mu$ per min. \\
\hline
\end{tabular}

* Conventions as in Table I. 
TABLE III

Summary of observations *

\begin{tabular}{|c|c|c|c|c|c|c|c|c|c|c|}
\hline & \multicolumn{5}{|c|}{ A. Noradrenaline, 10 cases } & \multicolumn{5}{|c|}{ B. Hexamethonium, 12 cases } \\
\hline & $\mathbf{P m}$ & RPF & GFR & $\mathbf{R}$ & $\mathbf{v}$ & $\mathbf{P m}$ & RPF & GFR & $\mathbf{R}$ & $\mathbf{v}$ \\
\hline $\begin{array}{l}\text { Mean } \\
\text { Range }\end{array}$ & $\begin{array}{l}1.07 \\
1.0-1.13\end{array}$ & $\begin{array}{c}.88 \\
.7-1.0\end{array}$ & .91 & $\begin{array}{c}1.25 \\
1.1-1.5\end{array}$ & $\begin{array}{l}1.39 \\
.7-2.9\end{array}$ & $\begin{array}{c}.85 \\
.7-.9\end{array}$ & $\begin{array}{c}.84 \\
.6-1.1\end{array}$ & $\begin{array}{c}.77 \\
.6-.93\end{array}$ & $\begin{array}{c}.93 \\
.8-1.2\end{array}$ & .25 \\
\hline
\end{tabular}

Noradrenaline after Hexamethonium

\begin{tabular}{|c|c|c|c|c|c|c|c|c|c|c|}
\hline & \multicolumn{5}{|c|}{ C. Recent injection, 6 cases } & \multicolumn{5}{|c|}{ D. Chronic treatment, 7 cases } \\
\hline & $\mathbf{P m}$ & RPF & GFR & $\mathbf{R}$ & $\mathbf{v}$ & $\mathbf{P m}$ & RPF & GFR & $\mathbf{R}$ & $\mathbf{v}$ \\
\hline $\begin{array}{l}\text { Mean } \\
\text { Range }\end{array}$ & $\begin{array}{c}1.19 \\
1.1-1.4\end{array}$ & $\begin{array}{l}1.08 \\
.9-1.4\end{array}$ & $\begin{array}{c}1.09 \\
1.0-1.2\end{array}$ & $\begin{array}{c}1.11 \\
1.0-1.3\end{array}$ & $\begin{array}{c}2.0 \\
1.2-2.6\end{array}$ & $\begin{array}{c}1.29 \\
1.1-1.6\end{array}$ & $\begin{array}{l}1.00 \\
.8-1.1\end{array}$ & $\begin{array}{l}1.13 \\
.9-1.3\end{array}$ & $\begin{array}{c}1.30 \\
1.0-1.7\end{array}$ & $\begin{array}{c}4.3 \\
1.0-1.3\end{array}$ \\
\hline
\end{tabular}

* Means of ratios of functions listed as Tables I and II. Ratios: (A) noradrenaline to control data and (B) hexamethonium to control data; (C) noradrenaline to status elicited by a single injection of hexamethonium and (D) to that existing during chronic hexamethonium treatment.

adrenaline infusion in the face of consistent, augmented increases of arterial pressure resulted from the varied changes in $\mathrm{C}_{\mathrm{PAB}}$, which was increased in 6 of the 13 tests, viz., in 4 instances of series I and 2 of series IV.

Glomerular filtration was increased by noradrenaline infusion in 7 of the 13 tests, on the average by about 10 per cent. Urine flow increased in 10 of these tests.

\section{Noradrenaline diuresis}

The diuretic effect of noradrenaline (Figure 1B) had no relation to pre-treatment with hexamethonium. Urine flows increased in patients whose filtration rates were not altered by noradrenaline infusion and in those whose filtration rates were somewhat increased. Small increases in urine flow were also observed in 3 patients whose rates of glomerular filtration were depressed during noradrenaline infusion by about 10 per cent, but in another 3 whose glomerular filtration rates were decreased 10 per cent or more, urine flow was also depressed.

\section{DISCUSSION}

Enhancement of pressor responsiveness to noradrenaline after treatment with hexamethonium is an instance of the general increased responsiveness

\section{A. HeXAMETHONIUM}

\section{B. moradremaline}

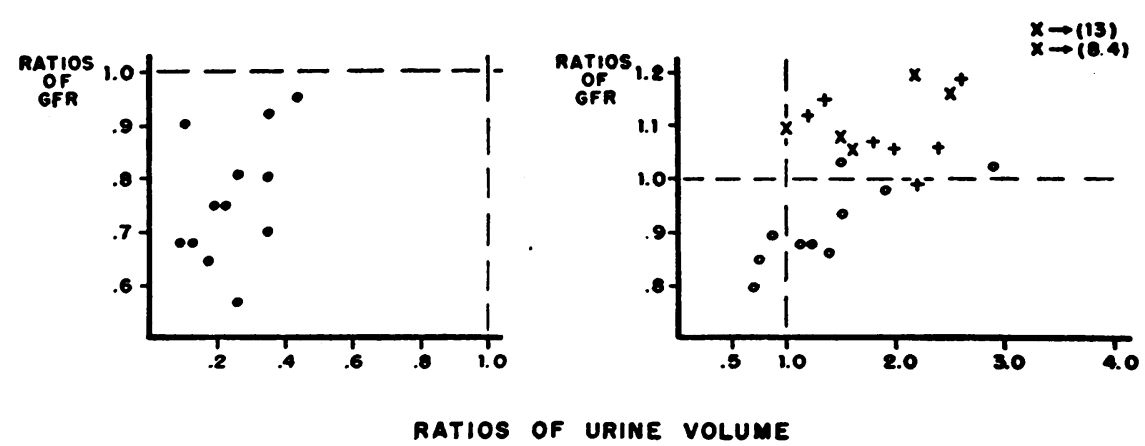

Fig. 1. Ordinates: Ratios of Glomgrular Filtration Rates (GFR) in Control as Compared with Test Periods. Abscissar: Ratios of Average Urine Volume in Control/Test Periods

A. Control: No treatment; tests, single injections of hexamethonium. B. Control : No pre-treatment (open circles), after single injections of hexamethonium (crosses) or during chronic treatment with hexamethonium ( $x$ 's): tests were infusion of noradrenaline. 
of blood pressure to vasoactive agents which is elicited by ganglion-blocking drugs (1). If it is assumed that the vasomotor center cannot homeostatically moderate changes in arterial pressure by reciprocal adjustments of vasomotor tone, this is a predictable response.

The increase in responsiveness to noradrenaline is greater, both in $\mathrm{mm}$. $\mathrm{Hg}$ pressure rise and in the final levels reached, in patients under chronic treatment than in those given only single injections of hexamethonium. This may be only a dosage effect, since it can be presumed that the effective body store of ganglion-blocker is greater in patients under continuous chronic treatment than in those given only single, moderately depressor doses. Alternatively, the difference may depend on the state of the arterial tree in these two groups of patients; in those given single injections, there is abrupt partial loss of vasomotor tone with resultant vasodilation, while most of the patients under chronic treatment had presumably regained their vasoconstricted state with the return of supine blood pressure to hypertensive levels. The difference in this case would result from the greater changes in peripheral resistance and blood pressure which should be elicited by equal degrees of vasoconstriction in a vasodilated as compared with a vasoconstricted vascular bed. Whatever the mechanism, the experiments confirm the suggestion (8) that doses of pressor agents which are only slightly effective under normal conditions may be severely pressor in patients under treatment with ganglion-blockers. Altered responsiveness doubtless also accounts for the decreased depressor activity of hexamethonium in patients given small (2 micrograms per minute) infusions of noradrenaline (9).

In dogs given TEAC, increased pressor responsiveness to noradrenaline is associated with increased renal vasoconstriction; this is not the case in patients given noradrenaline after pre-treatment with hexamethonium. Rather, such patients sustain variable effects of noradrenaline on renal plasma flow; prior to administration of the ganglion-blocker, noradrenaline consistently elicits renal vasoconstriction with little change in arterial pressure; after hexamethonium has been given, noradrenaline has irregular effects on renal plasma flow and fails to elicit increases in renal vascular resistance in a third of the tests, although blood pressures are consistently and sometimes severely increased.

The nature of this seeming failure of the renal vascular bed to participate in a pressor response attributable primarily to vasoconstriction is not clear. One consideration is that vascular disease may impair the 'autonomy of the renal circulation' of some patients with hypertensive disease. Such impairment would account for the renal bed sometimes responding as a passive system as it may during hypotension caused by spinal anesthesia (10) or, as in these experiments, during abrupt, large rises of blood pressure. Such passive responses are observed even in normal animals, such as in dogs brought into hypotension by bleeding, in which noradrenaline in amounts which return blood pressure to normal does not elicit consistent increases in renal vascular resistance (11).

Finally, the data indicate that noradrenalineinduced increases of urine flow are not proportionate to concurrent changes in filtration rate, except as the diuretic response is impaired or reversed by decreased rates of glomerular filtration; noradrenaline diuresis is not affected by hexamethonium.

\section{SUMMARY AND CONCLUSION}

1. The pressor effect of infused noradrenaline is enhanced in hypertensive patients given single injection or under chronic treatment with hexamethonium.

2. The renal vascular bed in hypertension in man does not regularly participate by increased vasoconstriction in this enhanced pressor response.

3. The oliguria which appears during the hour after a single intravenous injection of hexamethonium is associated with decreased glomerular filtration.

4. The increase in urine flow which usually occurs during infusions of noradrenaline is not affected by treatment with hexamethonium and shows no quantitative association with glomerular filtration except as it is impaired or reversed by decreased glomerular filtration.

\section{Addendum}

Since this manuscript was submitted, our attention has been drawn to the paper on "Reactivity to Pressor Agents in Hypertension" (Circulation, 1955, 12, 974) by A. E. Doyle and H. Black, in which they show that hy- 
pertensive patients yield larger pressor responses to angiotonin, S-methyl iso-thiourea and noradrenaline after hexamethonium than before and also larger increases in these responses than those in normotensive patients similarly tested.

\section{REFERENCES}

1. Page, I. H., and Taylor, R. D., Augmentation of vasoactive substances by tetraethylammonium chloride. Circulation, 1950, 1, 1233.

2. Corcoran, A. C., and Page, I. H., Renal hemodynamic effects of adrenaline and "Isuprel": Potentiation of effects of both drugs by tetraethylammonium. Proc. Soc. Exper. Biol. \& Med., 1947, 66, 148.

3. Page, I. H., and Corcoran, A. C., Arterial Hypertension; Its Diagnosis and Treatment. 2nd ed., Chicago, Year Book Publishers, 1949.

4. Haugen, H. N., and Blegen, E. M., The renal response to hexamethonium. Scandinav. J. Clin. \& Lab. Invest., 1953, 5, 58.

5. Ullmann, T. D., and Diengott, D., Effect of hexamethonium $\left(\mathrm{C}_{6}\right)$ on renal hemodynamics in man. Arch. Int. Med., 1953, 92, 228.
6. Moyer, J. H., and Mills, L. C., Hexamethonium-its effect on glomerular filtration rate, tubular function, and renal excretion of electrolytes. J. Clin. Invest., 1953, 32, 172.

7. Freis, E. D., Rose, J. C., Partenope, E. A., Higgins, T. F., Kelley, R. T., Schnaper, H. W., and Johnson, R. L., The hemodynamic effects of hypotensive drugs in man. III. Hexamethonium. J. Clin. Invest., 1953, 32, 1285.

8. Page, I. H., and Taylor, R. D., Mechanism of renin tachyphylaxis-restoration of responsiveness by tetraethyl ammonium ion. Science, 1947, 105, 622.

9. Doyle, A. E., and Smirk, F. H., The neurogenic component in hypertension. Circulation, 1955, 12, 543.

10. Moyer, J. H., Handley, C. A., and Huggins, R. A., The effect of adrenergic blockade and norepinephrine on renal and cardiovascular hemodynamics following hemorrhage. Circulation Research, 1954, $2,441$.

11. Corcoran, A. C., Taylor, R. D., and Page, I. H., Circulatory responses to spinal and caudal anesthesia in hypertension: Relation to the effect of sympathectomy. II. Effect on renal function. Am. Heart J., 1948, 36, 227. 